Review Article

\title{
Current Status, Challenges and Prospects of Mushroom Industry in Nepal
}

\author{
Jay Kant Raut \\ Faculty of Science, Nepal Academy of Science \& Technology, Khumaltar, Lalitpur, Nepal \\ Email address: \\ rautjk2000@yahoo.com
}

\section{To cite this article:}

Jay Kant Raut. Current Status, Challenges and Prospects of Mushroom Industry in Nepal. International Journal of Agricultural Economics. Vol. 4, No. 4, 2019, pp. 154-160. doi: 10.11648/j.ijae.20190404.13

Received: March 5, 2019; Accepted: April 12, 2019; Published: June 29, 2019

\begin{abstract}
This study attempts to analyze the current scenario of the mushroom enterprise in Nepal. The study provides insights on its future prospects as a major agro-industry. It also explores issues and challenges facing the Nepalese's mushroom industry by using a critical and SWOT analysis. Though, Nepal has all the requisites of low-cost labor, favorable climatic conditions, plentiful cheap supply of raw substrates, spawns and other inputs to become a leading mushroom producer. The industry is still in the state of infancy. The main challenges include inadequate scientific research on mushrooms; lack of adoption of improved technology, insufficient investment; unstable farm-gate prices and profit margins, poor supply and the increasing price of raw material e.g., rice straw; the poor quality of mushroom spawn, and the threat of diseases and pests attack. Several strategies are also presented here to improve the mushroom enterprise in Nepal.
\end{abstract}

Keywords: Consumption, Fungi, High-Tech Industry, Production, Trade

\section{Introduction}

Mushrooms are a type of higher fungus. They are neither plant nor animal belonging to their own separate biological kingdom Fungi. Approximately 14000 described species of the millions of fungi estimated in the world produce fruiting bodies that are large enough to be considered as mushrooms [1]. Among them, 7000 are considered to possess the varying degree of edibility and till now around 200 species have successfully been grown at laboratory scale. Sixty species have potentials for commercial cultivation. Currently, only more or less 10 species are farming at industrial scale in many countries [2-4]. Naturally, Nepal is very rich in mushroom diversity but due to limited scientific study only1150 mushroom species have been recorded so far. Among them, 147 are said to be edible, while 100 species are poisonous and 73 have medicinal values [5].

Undoubtedly mushrooms were one of human's earliest foods and in the past, they were often considered as exotic and luxurious food reserved for the rich only. But today mushrooms have become food for both the rich and the poor [6]. Mushroom cultivation can be traced back to around the 1600s in Europe but it wasn't until the 18th century in France that modern mushroom cultivation techniques began to form. During the $19^{\text {th }}$ century mushrooming became a popular leisure pursuit in Europe and America, and by the end of the century, mushroom societies were formed. Later at the end of 19th century, the farming technology entered in the USA via the Netherlands, Italy and other parts of Europe. After the Second World War, it was extended to more than 80 countries in the world [2]. Now the global mushroom industry has entered into a new era with the advancement of technology. In some developed countries of Europe and America, mushroom farming has attained the status of a high-tech industry with very high levels of mechanization and automation [7]. Edible cultivated mushrooms have become a symbol of reaping protein from waste. Through mushroom cultivation farm wastes have found a new way of being transformed to currency or high-value products. The technology that has been developed to cultivate these edible species of mushroom in a controlled environment is proving to be a newer means of eradicating poverty from the rural masses. In the era of healthy eating by cutting down the calories, saturated fat and cholesterol, mushroom are bound to attract the attention [8]. In fact, early herbalists recommended mushroom as a dietary 
substitute more due to its medicinal and nutritional values. Moreover, the Food and Agriculture Organization (FAO) has also recommended mushrooms as a food item contributing significantly to the protein nutrition of the developing countries like Nepal, which depend heavily on cereal diets [3, 8].

\section{Materials and Methods}

This study is mostly based on review and synthesis. A thorough search of the literature and database for relevant works is performed. The data for the study are acquired from secondary sources, such as reports published by the Food and Agriculture Organization (FAO), FAO database, Statistical Information on Nepalese Agriculture, Agri-Business Promotion and Statistics Division, Ministry of Agriculture Development, Kathmandu and other various types of published literatures. In the FAO database, mushrooms have been classified as FAOStat code 0449 and have been defined as including, inter alia, Boletus edulis, Agaricus campestris, Morchella spp., and Tuber magnatum. A critical analysis and SWOT analysis was carried out to evaluate the mushroom industry prospects in Nepal based on the recent national and international trends of mushroom production, consumption and import-export performance. The data used included the production volume, as well as the import and export information of fresh and processed products. SWOT analysis consists of four quadrants. Internal survey was used to highlight the strength and weakness. Meanwhile, the external survey was used to look at the opportunities and threats faced by mushrooms industry in Nepal

\section{Results and Discussion}

\subsection{Global Production}

The world mushroom production has increased at a rapid rate since the late 1990s. The production has increased more than 10-fold during the last four decades (Figure 1). As per the FAO statistics, the most notable increases occurred in China, Italy, the US, the Netherlands, India, and Vietnam. China has long been the world's largest mushroom producer country. China's present share in the total world mushroom production is more than $70 \%$ which was only $5.7 \%$ in 1978 and has maintained an annual growth rate of $10 \%$ for the last three decades. Mushroom is their sixth economically important crop in terms of country's revenue generation [8-9]. The second largest mushroom producing country is Italy followed by the United States of America, the Netherland, Poland, Spain, Iran, and other EU countries (Figure 2)

There are six major types (genera) of mushroom which contribute around $90 \%$ in total world production (Figure 3 ). Lentinula is the most widely grown mushroom accounting for over 2 million tons. The second most widely grown mushroom is Pleurotus spp. accounting around 0.4 million tons. Auricularia spp. is a close third, with six cultivated species; accounting 73840 tons constitute $18 \%$ of the world's total output while Agaricus bisporus contributes around 15\% accounting 11076 tons. The other two genera, Flammulina and Volvariella are responsible for $11 \%$ and $5 \%$ of the world's total output, respectively. Among the six Lentinula, Pleurotus and Agaricus are cultivated worldwide while the other three are grown almost exclusively in Asia [7, 10].

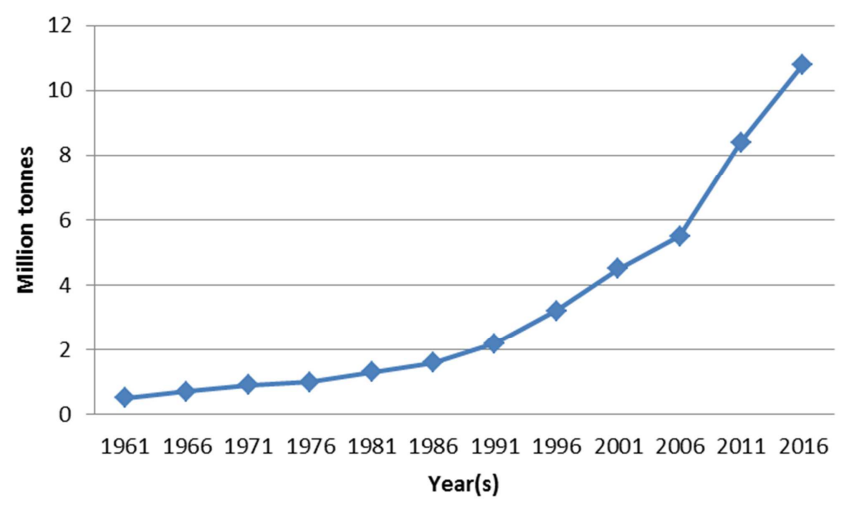

Figure 1. Global production of mushrooms \& truffles (Source: FAOSTAT; accessed on 10/5/2018).

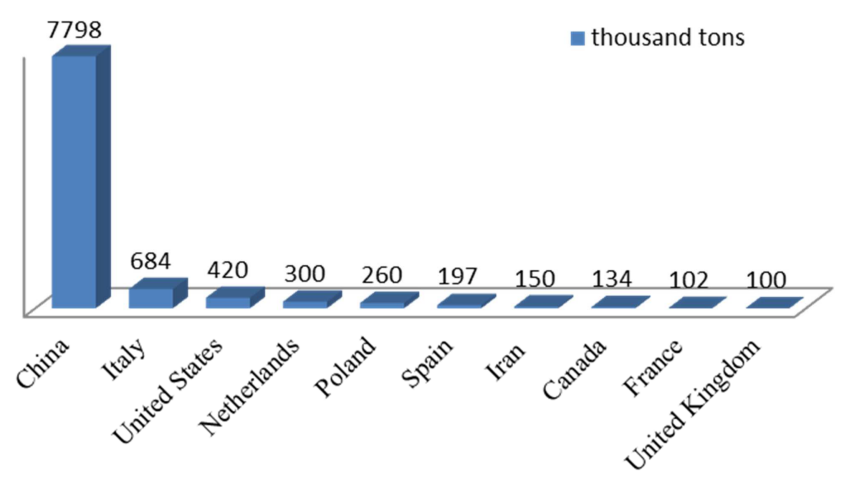

Figure 2. Top 10 mushroom producing countries in 2016 (Source: FAOSTAT; accessed on 10/5/2018).

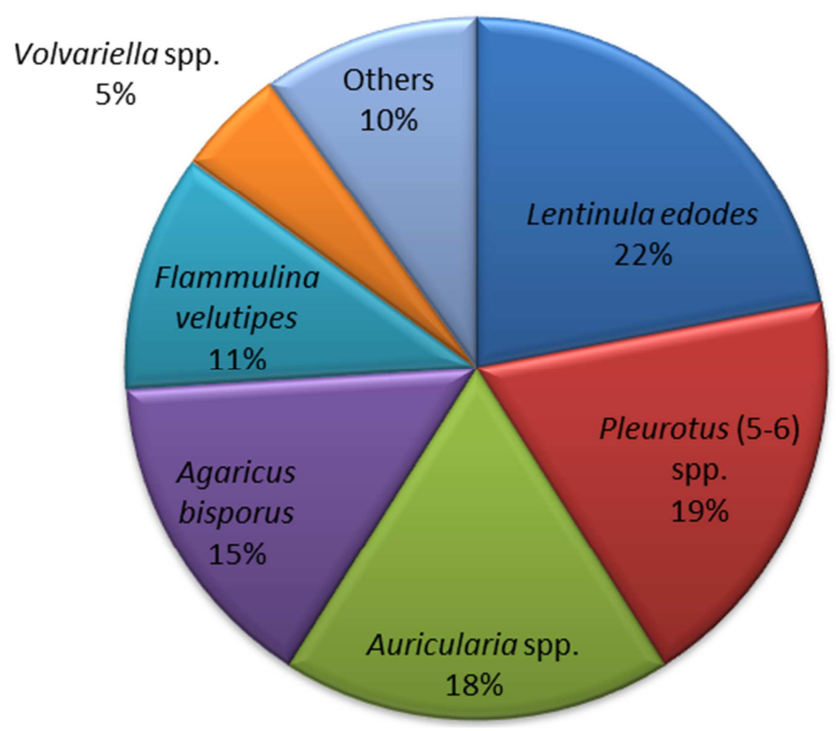

Figure 3. World edible mushroom production (\% of world's total output) by genus (2013). 


\subsection{Marketing and Trade}

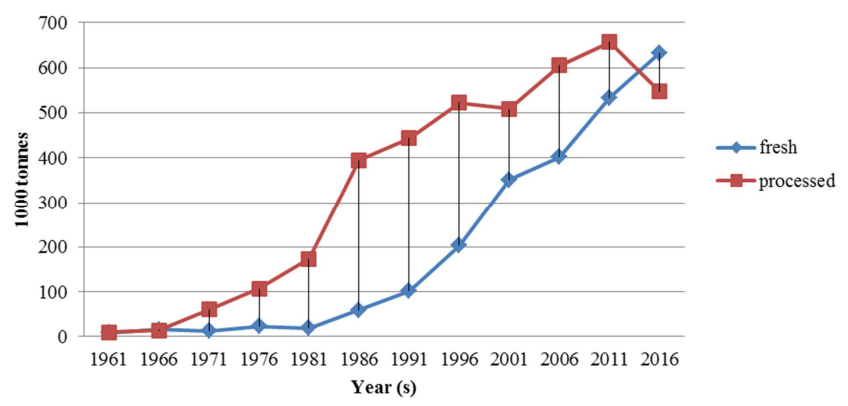

Figure 4. Trend of world processed (canned) and fresh mushroom export (Source: FAOSTAT; accessed on 11/15/2018).

Generally, mushrooms are traded in two forms: fresh and processed (canned, frozen, dried \& others as mushroom-based products) [11]. Processed mushrooms are projected to witness increased growth due to the rising demand for ready-to-eat food items. Presently, however, the fresh mushroom dominates the market due to easy availability of the same and the current preference of fresh food over processed (Figures 4, 5). Store-based such as convenience stores, specialty retailers, supermarket/hypermarket, and others sales of edible mushrooms have been observed to be the highest as consumers prefer to pick up fresh food in a one-stop shopping experience.

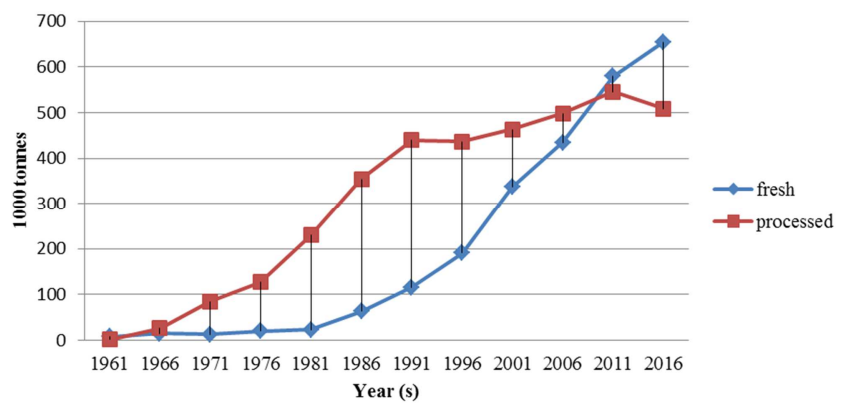

Figure 5. Trend of world processed (canned) and fresh mushroom import (Source: FAOSTAT; accessed on 11/15/2018).

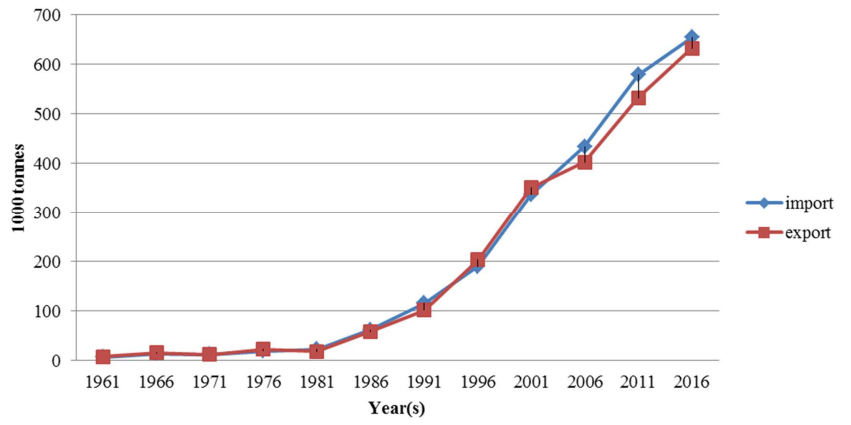

Figure 6. Trend of world mushroom and truffles import-export (Source: FAOSTAT; accessed on 11/15/2018).

The mushroom market has grown exponentially in the last few years and this trend is projected to continue (Figure 6). Increasing $\mathrm{R} \& \mathrm{D}$ on the benefits of mushrooms, rise in consumer awareness about health and wellness, growing awareness of the various varieties of mushroom and the innovative use of mushroom in meat substitute recipes are several critical factors that are expected to drive the global market. Rapidly expanding food industry in India and China also positively impact on the mushroom market [12].

North America and Europe are the most potent regions for the mushroom market. Europe is the largest market for the cultivation and processing of mushrooms. Therefore Europe accounted for more than $35 \%$ of the total market share in the mushroom processing and cultivation market [7]. There has been tremendous growth in demand for organic food in North America due to the growing incidence of diabetics and obesity in this region. Mushrooms possess nutritional properties such as low cholesterol and no fat. Hence mushroom is utilized as the staple food for patients suffering from obesity, high cholesterol, and others [3]. There has been the shift in preference for healthy and organic food from the health conscious populace has significantly contributed to the growth of the mushroom market in North America and Europe. Latin America is witnessing an unprecedented boom in recent times due to high use of mushroom as ingredients in various food products. Brazil market constitutes of several processed food products due to high demand from the consumers, this trend is expected to trigger the mushroom market growth. The Middle East and Africa exhibit decent growth in the next years due to the abundance of raw resources and favorable conditions for the mushroom growth $[7,11]$.

On the other hand, short shelf-life of mushrooms and the consequent packaging and storage issues are the major challenges faced by the mushroom market. Government regulations against the use of preservatives and additives that are proven harmful are also expected to hinder the growth of the global mushroom market. The loss incurred by these restraints can, however, be mitigated by the growing trend of using supermarkets and hypermarkets as a direct distribution channel for such perishable commodities [13]. Poland, Netherland, China, Canada, Belarus, Ireland, Lithuania, Belgium, Republic of Korea, Germany are the major mushroom and truffle exporting countries While countries like UK, Germany, USA, France, Belarus, Russian Federation, Thailand, Belgium, Lithuania, Netherland import the mushroom from above said exporting countries [14].

\subsection{Global Consumption}

Mushroom consumption has been increasing steadily throughout the globe. Health awareness and demand for meat substitutes have prompted global mushroom consumption. Mostly booming populations and rising incomes in countries like China, India and growing numbers of health-conscious consumers in developed countries are considered as major drivers of growth of mushroom consumption. Over a 15-year period (1997 to 2012), per capita consumption of mushrooms increased from about $1 \mathrm{~kg} /$ year to over $4 \mathrm{~kg} /$ year [9].

China is leading mushroom producer as well as consumer considering that $95 \%$ of mushroom production in China is consumed locally, the consumption per capita is likely to be over $10 \mathrm{~kg} /$ person/year. This is drastically higher than in the US and many European countries where it is around 3 
$\mathrm{kg} /$ person/year. In 2015 China alone consumed nearly 8181 thousand tones mushroom with $76 \%$ of global consumption share. The other major consumers were the United States (444 thousand tonnes) and Italy (324 thousand tonnes), with a share of $4 \%$ and $3 \%$, respectively. They were followed by the Netherlands with a $3 \%$ of global consumption share and Poland with a $2 \%$ share (Figure 7) $[7,13]$.

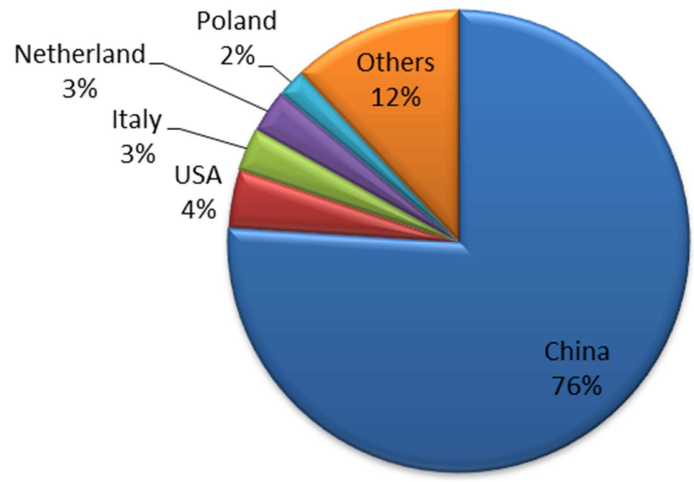

Figure 7. Top mushroom consuming countries in the world (2015).

\subsection{Mushrooms Farming Scenario in Nepal}

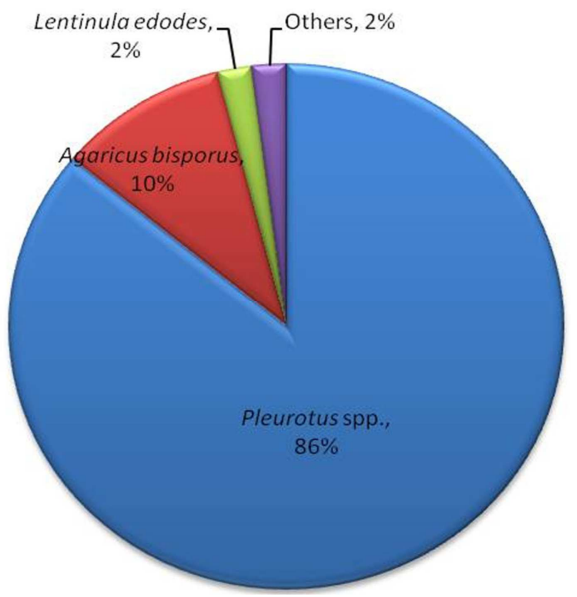

Figure 8. Mushroom production in Nepal by type (Source: Mushroom Producers Association, Nepal).

The tradition of collection and consumption of wild edible mushrooms by the various ethnic groups in different parts of Nepal have been very popular since ancient times. Artificial farming started in 1974 with button mushroom farming [15-16]. Though, there is great potential for year-round farming of a wide variety of mushrooms due to congenial agro-climatic condition and availability of wide variety of raw substrates (agricultural \& forestry wastes). Even today only a handful of species are grown commercially. Mainly white button (Agaricus bisporus) and Oyster (Pleurotus spp.) mushrooms are available in the local market to common consumers. Shitake (Lentinus edodes) and Milky mushroom (Calocybe indica) are other popular mushrooms in Nepal which have been farming on a commercial scale [17]. Currently, mushroom production is dominated by Oyster mushroom occupying $86 \%$ of total production which is followed by the white button (10\%) and Shitake (2\%) (Figure
8). Mushroom industry in Nepal is dominated by small-scale producers. According to the statistics by the Nepal mushroom producers association, there are around 2750 rural households engaged in mushroom production and related activities.

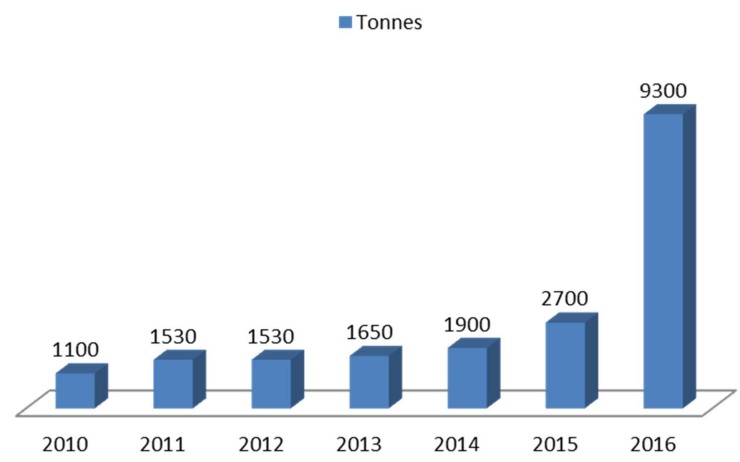

Figure 9. Fresh mushroom production in Nepal.

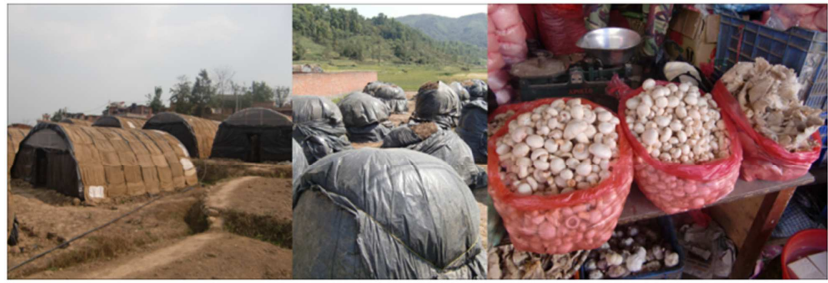

(b)

(c)

Figure 10. Current mushroom production \& market system in Nepal. (a) temporary low cost mushroom growing house (b) composting of straw in open place (conventional method) (c) mushroom for sale in a vegetable store.

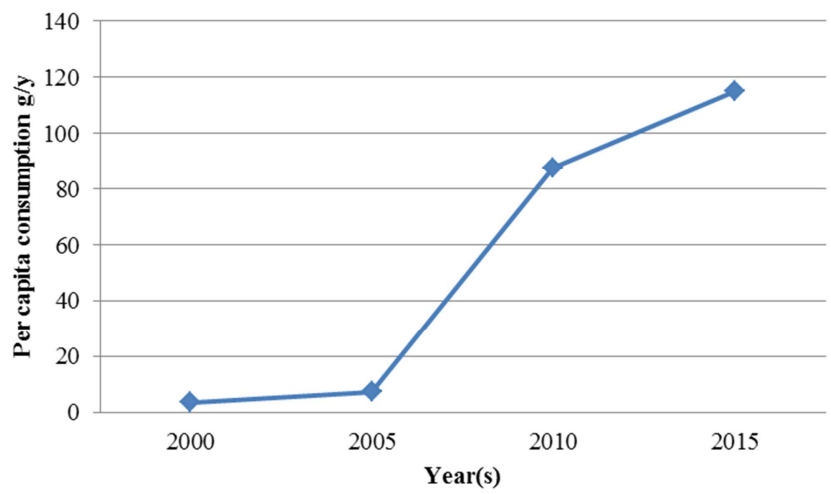

Figure 11. Trend of mushroom consumption in Nepal (Source: Based on FAOSTAT; accessed on 11/25/2018).

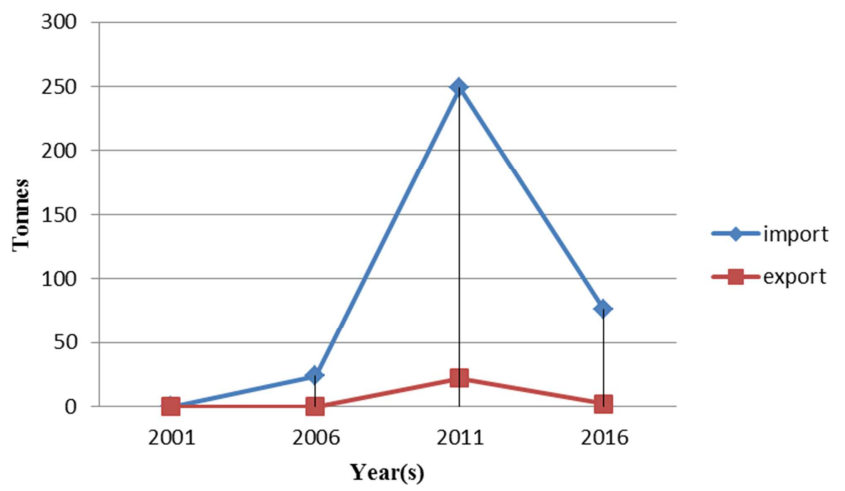

Figure 12. Import-export performance of mushrooms and truffles in or from Nepal (Item code 449) (Source: FAOSTAT; accessed on 11/25/2018). 
The production follows the upward trend. In 1974, the total output of mushroom was only $30 \mathrm{~kg}$ which has reached 9300 tonnes in 2016 (Figure 9) [18]. It indicates that the mushroom industry is gradually taking root in Nepal but the pace is rather slow. Mostly mushroom farming is seasonal under plastic tunnels (temporary low-cost mushroom growing house) (Figure 10). With the change in the food habit and the recognition of its nutritional and medicinal values domestic market is also increasing rapidly. The per capita consumption/year reached $115 \mathrm{~g}$ in 2015 from $4 \mathrm{~g}$ in 2000 (Figure 11). This increase can be taken as a highly encouraging sign coming from the potential mushroom consumers in Nepal. Current domestic production is insufficient to meet the local demand. To meet the demands Nepal has been importing a huge amount of mushrooms and its products from other countries annually. There is a huge trade deficit on this commodity (Figure 12). The rapid development of supermarkets in recent years is putting higher pressure on the fresh produce supply chain. They are increasingly demanding high-quality products and year-round stable supply. Large investments are needed to establish a modern mushroom farm, which requires not only state-of-the-art technology but also high-quality compost, improved cultivation, and the whole cooling chain

\subsection{SWOT Analysis on Nepalese Mushroom Industry}

A SWOT analysis was conducted based on the review. There are six strengths that need to be highlighted, with consideration of seven significant opportunities for greater benefit. Whereas, fifteen scores of weaknesses and four scores of threats must also be fully addressed (Table 1).

Table 1. SWOT analysis on mushroom industry.

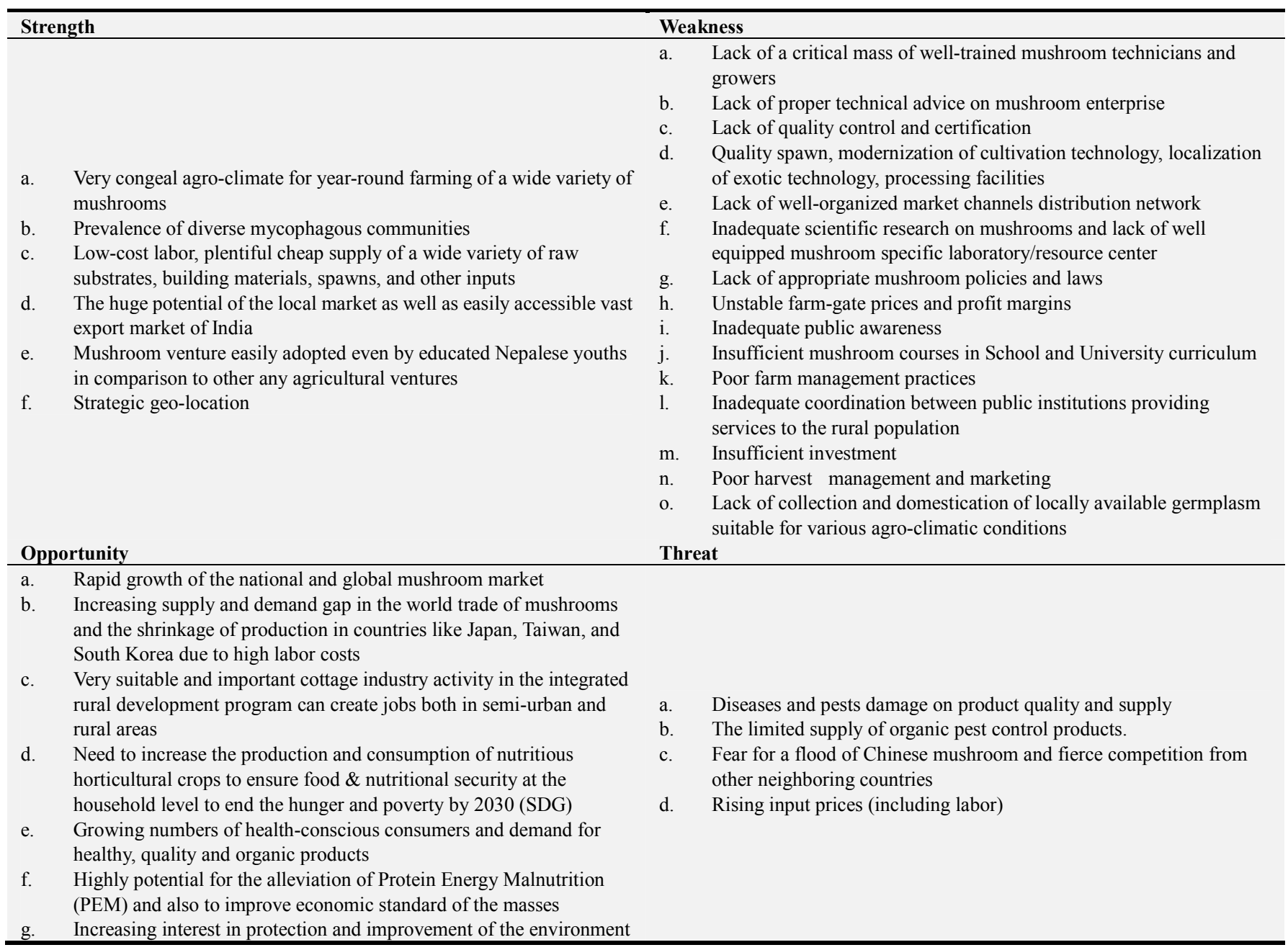

\subsection{Major Issues and Challenges of Mushroom Industry in Nepal}

There are several issues and challenges that are hindering the mushroom industry development in Nepal. Among them some major issues and challenges are listed here. The possible strategies to boost up the mushroom enterprises overcoming those issue and challenges are also suggested (Table 2). 
Table 2. Major issues and challenges of Nepalese mushroom industry.

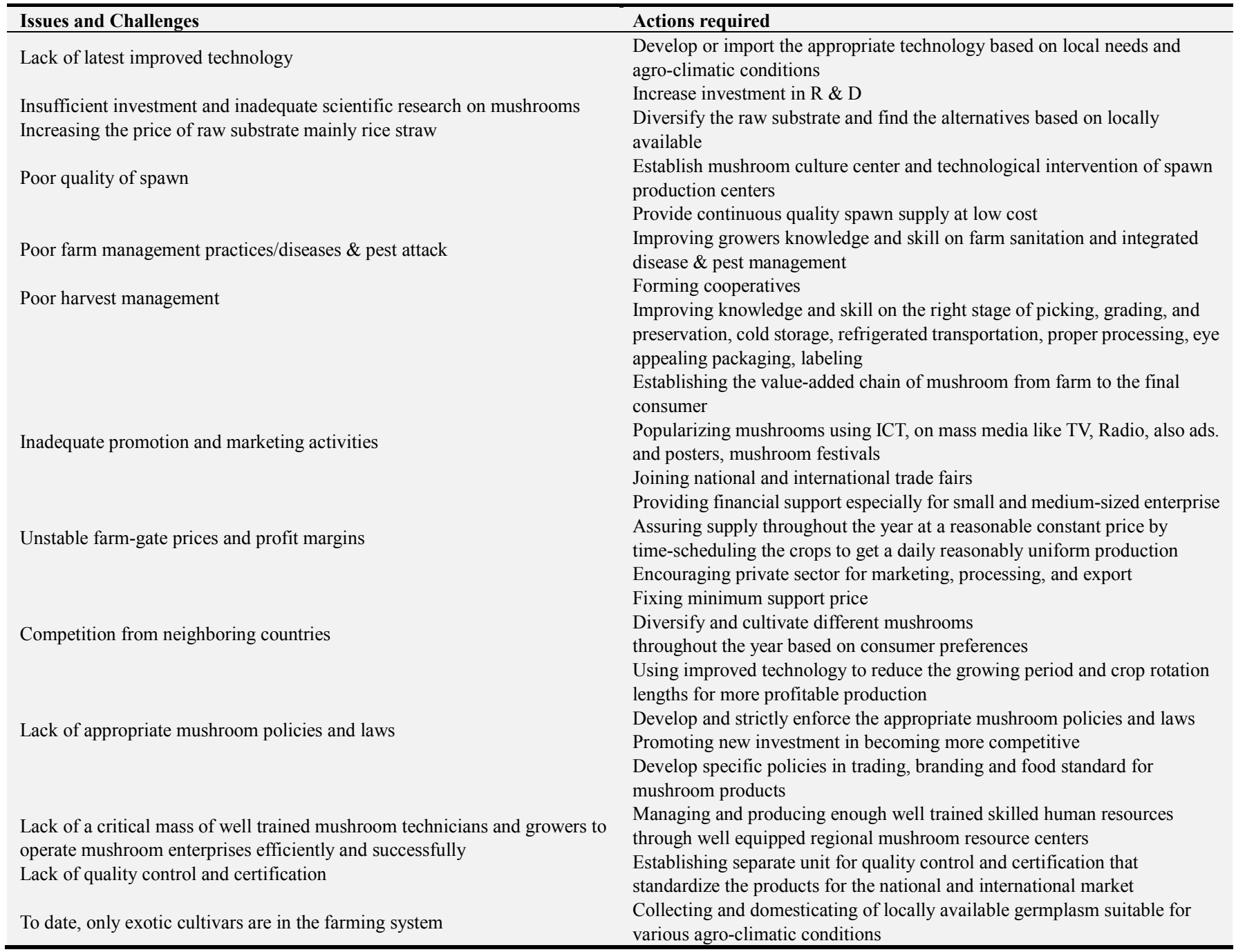

\section{Conclusion}

Like other developing countries Nepal is also an agriculture dominant country and huge quantities of wide varieties of organic waste are generated from agriculture, forestry, and food processing industries. Mushroom cultivation is an effective bioconversion technology of transforming these wastes into wealth or potentially valuable resources. The mushroom industry is gradually taking root in Nepal but the pace is rather slow because of insufficient scientific research and discourse. The increasing growth of mushroom production and consumption in Nepal seems a viable and attractive option. Mushroom cultivation could also be an important part of sustainable agriculture and forestry. Mushroom, a protein-rich wonder food needs more publicity as it deserves. It is then this precious vegetable would solve the problem of protein malnutrition within the country. In future, the ever-increasing population, depleting agricultural land, changes in the environment, water shortage and need for quality food products are going to be the vital issues. To meet these challenges and to provide food and nutritional security to our people, it is important to diversify the agricultural activities in areas like horticulture. Mushrooms are one such component that not only uses vertical space but also help in addressing the issues of quality food, health, and environmental sustainability. There is a need to promote both mushroom production as well as consumption for meeting the changing needs of food items. Thus, the mushroom sector holds huge potentials to contribute significantly to the nation's socio-economic transformation. Nepal can grab this potentiality enforcing a suitable and concrete national mushroom policy and plans.

\section{Acknowledgements}

The author would like to express his acknowledgements to P.N. Adhikari, President of Mushroom Growers Association Nepal for his valuable inputs in the manuscript.

\section{References}

[1] Kirk P., Cannon P. F., Minter D. W., Stalpers J. A. (2008) Ainswort \& Bisby's Dictionary of the Fungi, $10^{\text {th }} \mathrm{ed}^{\mathrm{n}}$. Wallingford: CAB International. 
[2] Chang S. T. (2006) The world mushroom industry: Trends and technological development. International Journal of Medicinal Mushrooms 8: 297-314.

[3] Chang S. T., Miles P. G. (2004) Mushrooms cultivation, nutritional value, medicinal effect, and environmental impact. United States, CRC Press.

[4] Martins A. (2017) The Numbers Behind Mushroom Biodiversity. In book: Wild Plants, Mushrooms and Nuts: Functional Food Properties and Applications (Eds. Isabel C. F. R. Ferreira, Patricia Morales, Lillian Barros) John Wiley \& Sons Ltd. DOI: 10.1002/9781118944653. pp.15-50.

[5] Adhikari M. K. (2014) Mushrooms of Nepal. (Eds by G. Durrieu, \& H. V. T. Cotter) Published by KS Adhikari, Kathmandu, Nepal. p. 340.

[6] Aneja K. R. (2001) Experiments in Microbiology, Plant Pathology, Tissue Culture and Mushroom Production Technology, New Age International (P) Ltd New Delhi-110002. pp. 496-519.

[7] Royse D. J., Baars J., Tan Q. (2017) Current Overview of Mushroom Production in the World. In book: Edible and medicinal mushrooms: technology and applications (Eds. Cunha Zied Diego \& Arturo Pardo-Giménez) John Wiley \& Sons Ltd. https: //doi.org/10.1002/9781119149446.ch2. p585.

[8] Zhang Y., Geng W., Shen Y., Wang Y., Dai Y. C. (2014) Edible Mushroom Cultivation for Food Security and Rural Development in China: Bio-Innovation, Technological Dissemination and Marketing. Sustainability 6: 2961-2973; doi: 10.3390/su6052961.

[9] Royse D. J. (2013) Trends in mushroom production worldwide. Pages: 38-47. In: Proceedings of the 7th International Symposium on Mushrooms in Brazil, Manaus, Brazil.

[10] Royse D. J. (2014) A global perspective on the high five: Agaricus, Pleurotus, Lentinula, Auricularia \& Flammulina. Proceedings of the $8^{\text {th }}$ International Conference on Mushroom Biology and Mushroom Products, New Delhi, India.

[11] Wakchaure G. C. (2011) Production and marketing of mushrooms: global and national scenario. In: M Singh, B. Vijay, S. Kamal \& G. C. Wakchaure, eds. Mushrooms Cultivation, Marketing and Consumption. Solan, Himachal Pradesh: Directorate of Mushroom Research. pp. 15-22.

[12] Rosmiza M. Z. Davies W. P., Rosniza Aznie C. R., Jabil M. J., Mazdi M. (2016) Prospects for Increasing Commercial Mushroom Production in Malaysia: Challenges and Opportunities. Mediterranean Journal of Social Sciences 7 (1 S1): 406-415.
[13] Karthick K., Hamsalakshmi H. (2017) Current scenario of mushroom industry in India. International Journal of Commerce and Management Research 3 (3): 23-26.

[14] FAO (2018) Food and Agriculture Organization of the United Nations. FAOSTAT Database. http: //faostat.fao.org (accessed on various dates).

[15] Manandhar K. L. (2004) Mushroom cultivation to make living in Nepal. Mushrooms growers' handbook 1. Mushworld. pp. $13-18$.

[16] Singh S. C. (2007) Status of mushroom cultivation in Nepal with reference to world production and consumption trends. In: Mycological Research and Mushroom production in Nepal (eds.) Singh SC, Adhikari MK, and Tiwari RD. The Mycological and Phytopathological Society, Nepal (MAPSON). pp. 1-19.

[17] Raut J. K. (2013) “Adhunik Chyau Kheti Prabidhi” (=Modern Mushroom Cultivation Technology) $1^{\text {st }}$ ed. Heritage Publisher \& Distributor Pvt. Ltd. Kathmandu, Nepal. p.150 (in Nepali).

[18] GoN (2001-2016) Statistical Information on Nepalese Agriculture. Ministry of Agricultural Development, Agribusiness Promotion and Statistics Division, Kathmandu, Nepal.

\section{Biography}

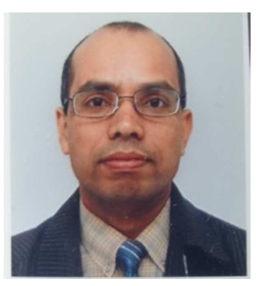

Dr. Jay Kant Raut is currently working as a mushroom scientist in Nepal Academy of Science \& Technology (NAST), Khumaltar Lalitpur. He has received his $\mathrm{PhD}$ degree in Mushroom Science (2011) from Graduate School of Horticulture, Chiba University, Japan. After completing his Master Degree in Botany (1997) from Tribhuvan University, he has been actively working in the field of Mycology. He is a founder member of International Society for Fungal Conservation and member of several other professional societies. Dr. Raut has more than one decade of teaching \& research experiences. Mushroom systematic \& nomenclature, mushroom biotechnology, mushroom cultivation, mushroom diversity \& conservation are the research fields of his interest. 